\title{
The effect of the problem-based learning model by using LKPD based on south sumatera's local superiority to learn outcomes
}

\author{
Rizki Fitrianti ${ }^{1}$, Nur Ahyani ${ }^{2}$, Dessy Wardiah ${ }^{2}$ \\ ${ }^{1}$ Sekolah Dasar Negeri 16 Prabumulih, Indonesia \\ ${ }^{2}$ Universitas PGRI Palembang, Indonesia
}

\begin{tabular}{l} 
Article Info \\
\hline Article history: \\
Received Jul $12^{\text {th }}, 2021$ \\
Revised Aug $15^{\text {th }}, 2021$ \\
Accepted Aug $30^{\text {th }}, 2021$ \\
\hline
\end{tabular}

\section{Keyword:}

Problem based learning model LKPD

\begin{abstract}
This study aimed to define the problem-based learning model of problem-based learning using LKPD based on South Sumatra's local benefits for students at SDN 16 Prabumulih learning outcomes. This study used Quasi Experimental Design as the Nonequivalent Control Group Design method of design. The mean pretest score in the experimental group was 82,6 and the mean pretest control score in the experimental group was 67,3. In the experimental population, pretest and posttest data were usually distributed with a value of $\mathrm{km}-0.71$ and 0.80 respectively. The hypotheses were calculated using ttest, which is polled variants, and the result of t obtained was 8,598 at 0,05 relevant level and table 1,987. Therefore, Ho was rejected and $\mathrm{Ha}$ was approved because the substantial level showed tobtain $>$ table. The results of this study showed that the impact model of problem-based learning using LKPD based on the local benefits of South Sumatra had a substantial impact on the learning outcomes of studies at SDN 16 Prabumulih.
\end{abstract}

(C) 2021 The Authors. Published by IICET.

This is an open access article under the CC BY-NC-SA license (https://creativecommons.org/licenses/by-nc-sa/4.0

\section{Corresponding Author:}

Fitrianti, R.,

Sekolah Dasar Negeri16 Prabumulih, Indonesia

Email: rizki30januari98@gmail.com

\section{Introduction}

Local excellence is all that is characteristic of regionalism, according to [1] which includes aspects of the economy, culture, information technology, connectivity, ecology, and so on. The goal of providing local excellence-based education is to allow learners to understand the local advantages of the area of residence, to understand aspects related to culture, traditions, and resources that are the advantages of an area, and to compete nationally and globally. In this research, local excellence is only centered on the city of Palembang and this local supremacy material will be related to the application of integrated thematic learning starting from one of the elementary schools' grade V themes, namely Ecosystems using the problem-based learning model, when coupled with South Sumatra's learning of local excellence. [2] Problem Based Learning (PBM) or Problem Based Learning (PBL) is a learning model based on the idea of using problems as a starting point for the development and incorporation of new knowledge, according to [1]. It also helps students to understand how to learn and work together in groups to use LKPD to find solutions to real-world problems.

LKPD is a written teaching material in the form of sheets containing content, summaries and directions that must be followed by students.

From the findings of interviews conducted by researchers on June 4, 2020 with SD Negeri 16 Prabumulih teachers of class V. In the 2013 curriculum, particularly in science lessons, teachers have not been able to 
develop LKPD by linking South Sumatra's local excellence to learning materials. The teacher monitors the content only, so that the touch of local learning excellence is always ignored. As a result, many students and even graduates do not know anything about their own region's capacity and community. This is inconsistent with the administration of education on the basis of Law No. 20/2003, (4) The administration of primary and secondary education by district or city governments, as well as education units on the basis of local excellence.

Based on the above definition, the researcher concludes that by connecting the local benefits of South Sumatra, it is important to provide an active and interesting learning worksheet in a lesson so that it can boost students' learning outcomes. To recognize the major effect on the learning outcomes of Class V students on Ecosystem Aspect Sub-Themes at SD Negeri 16 Prabumulih on the use of LKPD based on Local Excellence in South Sumatra. For this reason, researchers will conduct research on learning outcomes at SD Negeri 16 Prabumulih with the title "The Effect of Problem Based Learning Model Using LKPD Based on Local Excellence in South Sumatra on Learning Outcomes at SD Negeri 16 Prabumulih" The aim of the analysis was to evaluate and explain the impact of the Problem Based Learning model on the learning outcomes of class V students at SD Negeri 16 Prabumulih, in accordance with the problem formulation. To identify and describe LKPD based on Local Excellence in South Sumatra on the learning outcomes of SD Negeri 16 Prbumulih Class V students and to identify and describe the influence of student learning outcomes using the Problem Based Learning Model and LKPD based on Local Excellence in South Sumatra.

\section{Method}

The system of this study uses an experimental method with a type of Nonequivalent Control Group Design of the Quasi Experimental type. The Problem Oriented Learning Model is the independent variable (X1). The independent variable (X2) is LKPD, focused on South Sumatra's local excellence. The dependent variable (Y) is class V SD Negeri 16 Prabumulih's learning results. In this analysis, the group was 45 students in the experimental class and 45 control class students. In the academic year 2020/2021, the population used as a study was all grade V students at SD Negeri 16 Prabumulih, totaling 45 individuals, while the sample taken using a purposeful sampling technique was a determination technique with some considerations [3]. Class $\mathrm{V}$ control and experimental groups were allocated by the researcher, totaling 45 individuals at SD Negeri 16 Prabumulih and getting their address at JalanBangau No. 35, Karang Raja, Kec. East Prabumulih, South Sumatra Province, Prabumulih City. Tests, documentation, observations and questionnaires were the data collection methods used in this analysis..

\section{Results and Discussions}

The rise in learning outcomes is due to the learning process that has been carried out, and if it inked to opinions [11] it says that learning is an internal process which requires cognitive elements, where these internal elements communicate with the external world such that individuals or learners undergo changes. The disparity between the posttest results of the experimental class and the control class was affected by the fact that the experimental class included a Problem Based Learning Model Using LKPD Based on Local Excellence in South Sumatra at SD Negeri 16 Prabumulih. This time, the average observation result is only taken from the experiment class since the control class only takes cognitive data, so it can be seen from the average that is 6.73 and with the translation in the very active group, which is 22 students, the percentage of operation is 84.1 percent, There are 19 students in the active category and only 4 students are in the Enough category, which means that the observation is going well Based on the results of the normality test, it shows that in the Control class the value of the pretest curve slope $(\mathrm{km})$ is -0.71 and in the experimental class 0.80 . This shows that the data is normally distributed since the reception area $(-1)<\mathrm{km}<(+1)$ is fulfilled by the value of $\mathrm{km}$. This also demonstrates that the Posttest data is usually distributed as the $\mathrm{km}$ value matches the receiving region $(-1)<\mathrm{km}<(+1)$.

The data normality test results are usually distributed, then the data will be evaluated using the F-test or Fisher's test, which is the largest variance test separated by the smallest variance, for the similarity or homogeneity test. From the results of the T-test calculation, it is shown that the data obtained in the control class was $t=-5.840$ and the price of the $t$ table was $t=1.662$ for a 5 percent error level in the distribution table. Whereas in the experimental class it was obtained at tcount $>$ ttable for 5 percent error $(8,598>1,987)$ so it could be inferred that $\mathrm{H} 0$ was rejected and $\mathrm{Ha}$ was approved, which implies that there was a substantial difference in the posttest results of the experimental class and the control class.

Based on the results of the above discussion, it is demonstrated that South Sumatra's problem-based model of using LKPD based on local excellence has an impact on students' learning outcomes. This is because the 
LKPD Focused on Local Excellence problem-based model in South Sumatra helps students in the future phase of the city of Palembang and not only does it provide insight into student awareness. It is also possible to connect the problem-oriented model using LKPD based on local excellence in South Sumatra with learning materials, such as an example of learning the sub-theme of Ecosystem Components. Students are invited to learn about the local benefits that exist in a region, particularly in the city of Palembang, during this activity.

\section{Conclusions}

Based on the results of the above discussion, it is demonstrated that South Sumatra's problem-based model of using LKPD based on local excellence has an impact on students' learning outcomes. This is because the LKPD Focused on Local Excellence problem-based model in South Sumatra helps students in the future phase of the city of Palembang and not only does it provide insight into student awareness. It is also possible to connect the problem-oriented model using LKPD based on local excellence in South Sumatra with learning materials, such as an example of learning the sub-theme of Ecosystem Components. Students are invited to learn about the local benefits that exist in a region, particularly in the city of Palembang, during this activity.

\section{References}

Suratmi and others, 2017. South Sumatra Local Excellence as a center of learning for STEM education. South Sumatra: Biology Education, Elementary School Teacher Education at Sriwijaya University.

Saleh, Muhammad Muhammad (2013). Fiqh with Problem-Based Learning Learning Approach. Jakarta: Tarbiyah Faculty and UIN SyarifHidayatullah's Teacher Training.

Sugiyono. 2017. Methods of Research and Development Research \& Development. ALFABETA: Bandung. Fatimah. 2016. Educational growth in State Vocational High Schools of Tapin Regency on Local Characterist 